\title{
Uma edição de ouro: Vida e obra de Virgínia Victorino
}

\section{A gold edition:}

Vigínia Victorino's life and word 
Apesar de publicado em Dezembro de 2019, numa edição cuidada, de enorme requinte, com inexcedível apoio de diversas entidades e, em especial, por José Guilherme Victorino e a Faculdade de Letras da Universidade de Lisboa e a Câmara Municipal de Alcobaça, não é tarde para aqui sublinharmos a importância de Virgínia Victorino - Vida e Obra, até porque, a reboque do congresso internacional realizado em Setembro de 2019, novo encontro se fez em Lisboa, com participações de enorme relevância (destacaria Ruy Vieira Nery que dedicou à autora de Namorados um delicado e aprofundado estudo), vincando bem dois factos: que Virgínia Victorino merece a atenção dos investigadores e que, na mesma senda de revitalização da sua obra, teremos de prestar também atenção ao trabalho levado a cabo por estudiosos que, nem sempre, estão no plano que lhes é devido. Dois exemplos: Isabel Lousada, excelente organizadora do congresso de Setembro de 2019 e, primacialmente, Jorge Pereira de Sampaio. Este último é hoje, autorizadamente, um dos maiores especialistas no que que tange à obra de Virgínia e este livro que Sampaio organizou coloca-o na primeira linha do que em Alcobaça venham a ser as iniciativas culturais directa ou indirectamente relacionadas com a poeta-dramaturga.

0 livro em causa, que marca os 50 anos da morte de Virgínia Victorino divide-se em nove capítulos, a saber: "De Alcobaça a Lisboa (1895-1926); «Virgínia Victorino e a Poesia»; «Virgínia Victorino: Amizades e Cumplicidades»; Virgínia Victorino e a 0 Teatro»; «0 Reconhecimento Público pelo Estado Português e Espanhol»; «Conservatório e Emissora, a sua vida profissional», «Impacto de uma escritora portuguesa além-fronteiras», «Aposentação nas Caldas da Rainha» e «Em Memória de Virgínia Victorino». Num volume com cerca de 315 páginas, de impressão sóbria, acompanhada de fotografia, convém destacar o prefácio de Maria Victoria SanchésElez da Universidade Complutense de Madrid, segundo a qual esta edição se torna incontornável para quem quiser aprofundar as relações entre Portugal e Espanha no que tange à criação literária da primeira metade do século $X X$.

Se Jorge Pereira de Sampaio é, como diz a catedrática, um autor prolífico em vários domínios (museulogia, cerâmica, antiguidades), certo é que se afirma, com este e outros livros já por si editados ou vindos a lume em diversas chancelas editoriais, como conhecedor profundo das relações humanas e culturais que Virgínia cultivou e com semelhante saber transcende este livro a mera fotobiografia. Não está em causa reconhecer apenas o eco que a autora teve em Portugal e no Brasil, mas convidar ao exercício da memória. Que livro de poesia conheceu em Portugal 12 edições no nosso país e duas em terras de Vera Cruz? Namorados, livro de estreia da autora, se não tinha a irrupção emocional que uma outra contemporânea, Florbela, deixava adivinhar, tinha, decerto, esse equilíbrio entre emoção e realismo dos sentimentos que Virgínia, como apontaram diversos leitores na sua época, transfigurava de forma superior.

De resto, convém ter em conta - como este Virgínia Victorino - Vida e Obra destaca - o papel crucial da autora de Renúncia (incensado por Hernâni Cidade) na afirmação do papel da mulher intelectual portuguesa num tempo adverso. Paulo Guinote, precisamente na comunicação que pronunciou no Congresso Internacional em Alcobaça, não esqueceu essa dimensão simultaneamente política e social que coube à escritora. Da mesma geração que Branca Colaço, Fernanda de Castro, Virgínia Madeira, Oliva Guerra e Florbela Espanca, certo é que, como escreveu Agostinho de Campos, era na sua poesia que se encontrava a voz de 
uma geração de mulheres-escritoras que anseavam por quebrar os grilhões ideológicocomportamentais. Não por acaso, logo em 1917, Catarino da Silva incluía-a na sua Antologia de Escritoras Portuguesas e Júlio Dantas, pouco depois, não hesitou em considerá-la a «musa do soneto». Maria Lúcia Dal Farra, a maior especialista nos estudos florbelianos e investigadora celebrada dos estudos sobre literatura no feminino dá-nos bem a medida da sua importância no verbete que assina para o Dicionário de Fernando Pessoa e do Modernismo Português.

Outros, de que são nomes cimeiros Fidelino de Figueiredo, mas, nos nossos dias, José Carlos Seabra Pereira, acentuam, na linguagem poética e na dramaturgia de Virgínia a segurança rítmica, a sedução por um universo vocabular extremamente preciso e tangencial a essa feminina visão de mundo colocada entre vontade de expressão e consciência da opressão. Um dado que lemos através de Jorge Pereira de Sampaio: que escritores viviam exclusivamente da venda dos seus livros aquando da grande crise do sector livreiro de 1929, fruto da Grande Depressão? Raúl Brandão, Aquilino Ribeiro, Antero de Figueiredo e a nossa autora. Isto além de autores da chamada «novela de amor humilde», como era o caso de Norberto de Araújo.

Albino Forjaz de Sampaio em 1935 colocava o nome de Virgínia no topo do cânone da poesia feminina nacional e anos mais tarde, em 1951, por ocasião da Exposição de Livros Portugueses em Paris, era Virgínia Victorino lembrada pelos seus poemas e edições dos anos vinte e trinta. Dominantes neoromânticas, assunção dum amor vivido sem freios (Anna Klobucka), e depois da poesia a entrega ao teatro e à divulgação cultural em programas de rádio de enorme audiência, tudo é escrutinado por Jorge Pereira de Sampaio num livro, quero crer, que aos leitores atentos e investigadores da literatura não poderá mais ser ignorado.

Justamente neste contexto, a atribuição do Prémio Joaquim Veríssimo Serrão ao maior investigador vivo da vida e obra da autora de Namorados, reveste-se de uma importância capital. Jorge Pereira de Sampaio torna-se, assim, nome incontornável da investigação sobre cultura portuguesa e as tangentes que áreas como a literatura e a museulogia ou a antiquária nas primeiras três décadas de novecentos entre si estabelecem. No quadro dessa investigação aturada, discreta, inteligente, Pereira de Sampaio, apaixonado por tudo quanto a Alcobaça diga respeito, foi 0 responsável pela organização do Congresso Internacional Virgínia Victorino que, em Setembro de 2018 naquela cidade celebrou a poetisa maior da década de 1920. 0 prémio agora outorgado pode e deve fazer-nos regressar ao belo volume que, nessa ocasião, espelhou bem todo o labor do agora premiado. 